\title{
NARRATIVE REVIEW
}

\section{How to ventilate obese patients in the ICU}

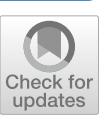

\author{
Audrey De Jong ${ }^{1}$, Hermann Wrigge ${ }^{2,3,4}$, Goran Hedenstierna ${ }^{5}$, Luciano Gattinoni ${ }^{6}$, Davide Chiumello ${ }^{6,7,8}$, \\ Jean-Pierre Frat ${ }^{9,10}$, Lorenzo Ball ${ }^{11,12}$, Miet Schetz ${ }^{13}$, Peter Pickkers ${ }^{14}$ and Samir Jaber ${ }^{1 *}$ (D
}

(c) 2020 Springer-Verlag GmbH Germany, part of Springer Nature

\begin{abstract}
Obesity is an important risk factor for major complications, morbidity and mortality related to intubation procedures and ventilation in the intensive care unit (ICU). The fall in functional residual capacity promotes airway closure and atelectasis formation. This narrative review presents the impact of obesity on the respiratory system and the key points to optimize airway management, noninvasive and invasive mechanical ventilation in ICU patients with obesity. Non-invasive strategies should first optimize body position with reverse Trendelenburg position or sitting position. Noninvasive ventilation (NIV) is considered as the first-line therapy in patients with obesity having a postoperative acute respiratory failure. Positive pressure pre-oxygenation before the intubation procedure is the method of reference. The use of videolaryngoscopy has to be considered by adequately trained intensivists, especially in patients with several risk factors. Regarding mechanical ventilation in patients with and without acute respiratory distress syndrome (ARDS), low tidal volume (6 $\mathrm{ml} / \mathrm{kg}$ of predicted body weight) and moderate to high positive end-expiratory pressure (PEEP), with careful recruitment maneuver in selected patients, are advised. Prone positioning is a therapeutic choice in severe ARDS patients with obesity. Prophylactic NIV should be considered after extubation to prevent re-intubation. If obesity increases mortality and risk of ICU admission in the overall population, the impact of obesity on ICU mortality is less clear and several confounding factors have to be taken into account regarding the "obesity ICU paradox".
\end{abstract}

Keywords: Obesity, Obese, HFNC, Mechanical ventilation, NIV, Prone position, Prone positioning, ARDS, COVID-19

\section{Introduction}

Obesity (defined by a body mass index (BMI) $\geq 30 \mathrm{~kg} /$ $\mathrm{m}^{2}$ ) is a disease caused by excess or abnormal distribution of fat tissue and resulting in chronic diseases related to chronic inflammation and metabolic dysfunction [1]. Obesity has become a global epidemic with prevalences rising both in developed and developing countries. Front runners in 2020 are the United States of America (USA, $36 \%$ ) and Australasia (30\%), with a prevalence expected to increase in the USA until $50 \%$ by 2030 [2], whereas

\footnotetext{
*Correspondence: s-jaber@chu-montpellier.fr

${ }^{1}$ Research Unit: PhyMedExp, INSERM U-1046, CNRS, Anesthesia

and Critical Care Department (DAR-B), Saint Eloi, University of Montpellier, 34295 Montpellier, cedex 5, France

Full author information is available at the end of the article
}

European countries have prevalences between 20 and $30 \%$. The percentage of patients with obesity in the intensive care unit (ICU) can be expected to increase concomitantly or even more since obesity increases the risk for a more severe disease course with more need for ICU admission and mechanical ventilation [3] as has been shown in trauma [4], traumatic brain injury [5] patients, out-of-hospital cardiac arrest [6], during the H1N1 pandemic [7] and recently also in patients affected by coronavirus disease 2019 (COVID-19) [8-11].

Obesity, especially abdominal obesity (android fat distribution) and severe obesity [12], results in altered respiratory anatomy and physiology and, therefore, complicated airway management and adapted ventilator settings during mechanical ventilation. Obesity appears to be associated with an increased risk of acute respiratory distress syndrome (ARDS) [13] and infection, mainly pneumonia [14], probably related to an imbalanced

\section{勿


production of adipokines [15]. In ventilated patients, obesity increases ICU length of stay and the duration of mechanical ventilation [16]. The phenomenon whereby obesity increases morbidity but seems to protect against mortality in selected critically ill patients, known as "obesity paradox", has been evocated in patients with ARDS [13] and in those on mechanical ventilation [16], even if it remains highly debated.

This narrative review will summarize current insights into the impact of obesity on the respiratory system and the measures to be taken to optimize airway management and mechanical ventilation in ICU patients with obesity.

\section{Respiratory modifications: pathophysiology}

The patient with obesity suffers from increased respiratory workload and impaired gas exchange. Both disturbances reduce physical capacity and health margin if exposed to respiratory stress. A basic triggering factor is reduced lung volume, caused by cranial displacement of the diaphragm by increased tissue mass in the abdomen, and by increased chest wall tissue. The decrease in resting lung volume after normal expiration, functional residual capacity (FRC), is $5-15 \%$ per $5 \mathrm{~kg} / \mathrm{m}^{2}$ increase in BMI [17]. The consequence of the increased tissue mass will be greater in the supine than upright position, due to a stronger cranial displacement of the diaphragm. In addition, a further decrease in the FRC can be seen during anesthesia with loss of respiratory muscle tone and, most likely, in ICU by the use of sedatives and muscle relaxants. The fall in FRC promotes airway closure and atelectasis formation, as will be discussed later, and an illustration of one representative case with no ventilation in the dorsal part of the lung, likely because of dependent atelectasis formation [18], is shown in Fig. 1.

\section{Take-home message}

In patients with obesity, using non-invasive ventilation (NIV) is advised both to prevent and treat acute respiratory failure. When invasive mechanical ventilation is needed, pre-oxygenation with NIV and appropriated choice of intubation devices will decrease complications. During invasive mechanical ventilation, patients with obesity are more prone to lung collapse and require higher PEEP to avoid it; low $V_{T}$ is calculated on predicted body weight. When acute respiratory distress syndrome occurs, careful recruitment maneuver might be used associated with prone positioning.

There are several causes of increased work of breathing in the patient with obesity. One is the increased displacement of tissue during the breathing, both in the abdomen and in the lung and chest wall. Another is increased airway resistance because of smaller airway dimensions, and increased asthma incidence. Finally, increased tissue resistance adds to the work of breathing [19]. The patient with obesity may easily develop respiratory fatigue on physical exercise and, in the most severe cases, already at rest.

It is often assumed that chest wall elastance or its inverse, chest wall compliance, is affected by obesity. However, the increased weight of the abdomen and of the chest wall requires work when moving the tissue, but when the move is over, no additional pressure is required [19]. End-inspiratory and end-expiratory pauses should be long enough when measuring chest wall compliance. Lung compliance, on the other hand, is reduced [20]. The decreased lung volume may require pressure during inspiration to open closed units, and that may be recorded as a decrease in compliance.

Airways may close in dependent lung regions during an expiration, a normal age-dependent phenomenon.

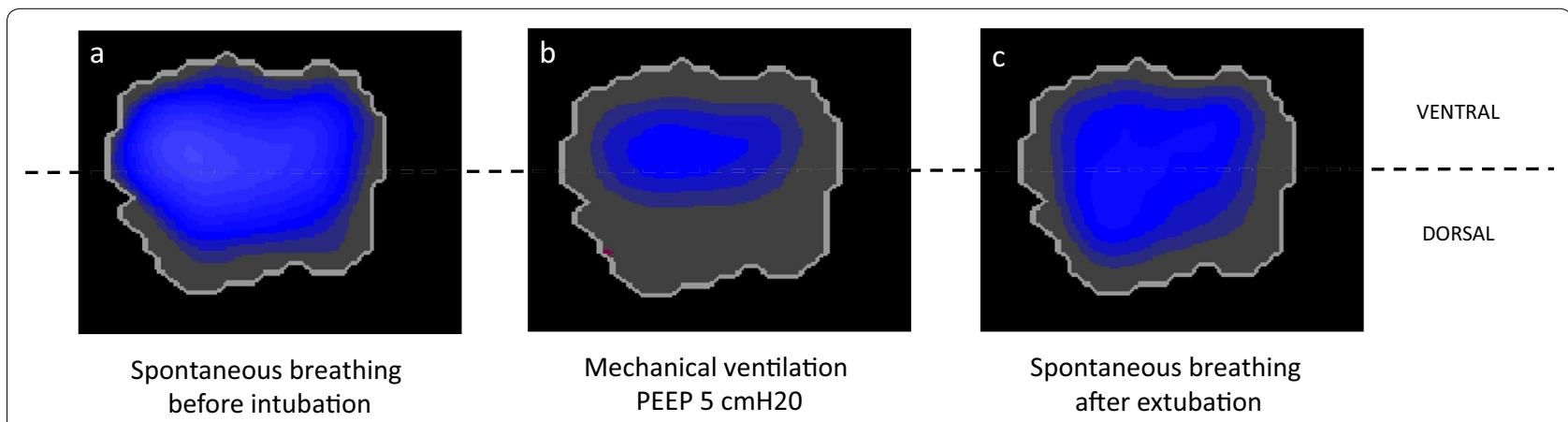

Fig. 1 Impedance changes due to regional ventilation in a patient with obesity. Thoracic transversal electric impedance tomography images show impedance changes due to regional ventilation summarized for tidal ventilation cycles in a patient with a body mass index of $57 \mathrm{~kg} / \mathrm{m}^{2}$. Images were recorded during spontaneous breathing before intubation (a) and about $1 \mathrm{~h}$ after extubation (c) in a patient without lung pathology. Note the ventral shift of ventilation during mechanical ventilation with a positive end-expiratory pressure $(\mathrm{PEEP})$ of $5 \mathrm{~cm} \mathrm{H}_{2} \mathrm{O}(\mathbf{b})$, which is likely due to atelectasis formation in dependent lung areas. Obviously, the PEEP level was insufficient to keep the lung open 
While this has been known for many years, a more extensive, indeed complete airway closure has been shown during the last few years in anesthetised patients with obesity [21] or ICU patients with obesity on mechanical ventilation. This means that a certain airway pressure is needed to start inflation of the lungs and it is not caused by a time-dependent intrinsic positive end-expiratory pressure (PEEP). Where the complete closure occurs is not clear but may be in the most central airways and not in the periphery. The latter would require simultaneous closure of thousands of airways, as recently discussed [22]. Hopefully, the morphology behind complete closure can be demonstrated in the near future.

A consequence of the classic airway closure is impeded ventilation where the closure occurs and the decrease in ventilation will be larger the longer the closure lasts during the respiratory cycle. If airways are continuously closed, as can be seen during anesthesia and most likely in ICU, the alveoli distal to the closure will collapse because of gas absorption [23]. The higher the oxygen concentration is in the inspired gas, the faster is the collapse. With pure oxygen, it can take a few minutes and with air, a couple of hours. The complete closure, on the other hand, will delay onset of inspiration without affecting the distribution per se.

Uneven ventilation distribution caused by airway closure will occur primarily in dependent lung regions. Perfusion of the lung, on the other hand, increases down the lung independent of anatomy. Regions that are poorly but still ventilated will cause ventilation-perfusion mismatch and regions that collapse because of continuous airway closure will cause shunt [23]. Both impede oxygenation [24] and a large shunt may even impair carbon dioxide $\left(\mathrm{CO}_{2}\right)$ elimination. With an extreme shunt, oxygenation is poorly or not at all improved by increasing oxygen in the inspired gas. Finally, in patient with obesity, there is significant heterogeneity in both resistance and compliance, Therefore, inhomogeneous inflation or deflation of the lungs can cause dynamic pressure differences between regions and lead to interregional airflows known as pendelluft effect.

However, the patients with obesity are not a homogeneous group regarding the physiological modifications, the level of obesity and the fat distribution (gynoid versus android) being confounding factors that should be taken into account.

\section{Management of the acute respiratory failure patient}

Although hypoxemic acute respiratory failure (ARF) is not the first cause of ARF in the patient with obesity [25, 26], hypoxemia is frequent as it is favored by increased oxygen consumption or work of breathing and atelectasis formation, especially in cases of patients with morbid obesity and during ARF [27]. Non-invasive strategies should first optimize body position with reverse Trendelenburg position, "beach chair position" or sitting position, which improve respiratory compliance and gas exchange in patients with morbid obesity $[28,29]$.

In patients having postoperative hypoxemia or ARF, non-invasive ventilation (NIV) is recommended with moderate certainty of evidence, justified by a decreased need of intubation, mortality and morbidity as compared to standard oxygen [30, 31]. An observational study including 72 patients with ARF after abdominal surgery reported that NIV avoided intubation in $67 \%$ of cases [32]. In a post hoc analysis of a large trial of 830 postoperative thoracic patients [33], it was shown that among the 272 patients with obesity (mean BMI of $34 \mathrm{~kg} / \mathrm{m}^{2}$ ), NIV was not superior to high-flow nasal cannula oxygen therapy (HFNC), with treatment failure occurring in $15 \%$ and $13 \%$ in NIV and HFNC groups, respectively. Therefore, NIV could be considered as the first-line therapy in patients with obesity having a postoperative ARF [34], but further studies are needed to confirm the role of Continuous Positive Airway Pressure (CPAP) and/or HFNC in this setting $[35,36]$ (Table 1).

Data addressing the management of hypoxemic ARF with non-invasive ventilatory/oxygen strategies are scarce, especially in patients with obesity. The recent international guidelines failed to offer a recommendation on the use of NIV in hypoxemic ARF [30]. One large trial has compared NIV with standard oxygen and HFNC in 310 non-selected patients with hypoxemic ARF [37]. Results showed lower mortality rates with HFNC than NIV, thereby suggesting deleterious effects of NIV. Similarly, an observational study including 76 patients with BMI $>40 \mathrm{~kg} / \mathrm{m}^{2}$ showed that, after adjustment on high severity scores, hypoxemic ARF caused by pneumonia was associated with NIV failure [38]. However, according to physiological abnormalities in patients with obesity, NIV could play a role, especially in patients with morbid obesity, through PEEP that may improve oxygenation and lung volume or alveolar recruitment [39]. Finally, possible use of NIV or HFNC as alternative to standard oxygen in patients with obesity and hypoxemic ARF is not determined, and future trials are needed (Table 1).

Hypercapnic ARF in patients with obesity can not only be part of the clinical course of cardiogenic pulmonary edema, pneumonia, asthma, and exacerbation of chronic lung diseases, but also may be due to exacerbation of obesity hypoventilation syndrome (OHS) [40]. Positive airway pressure, i.e. CPAP (refer to one level of airway pressure) or NIV (refer to two levels of airway pressures), is the recommended ambulatory treatment for 


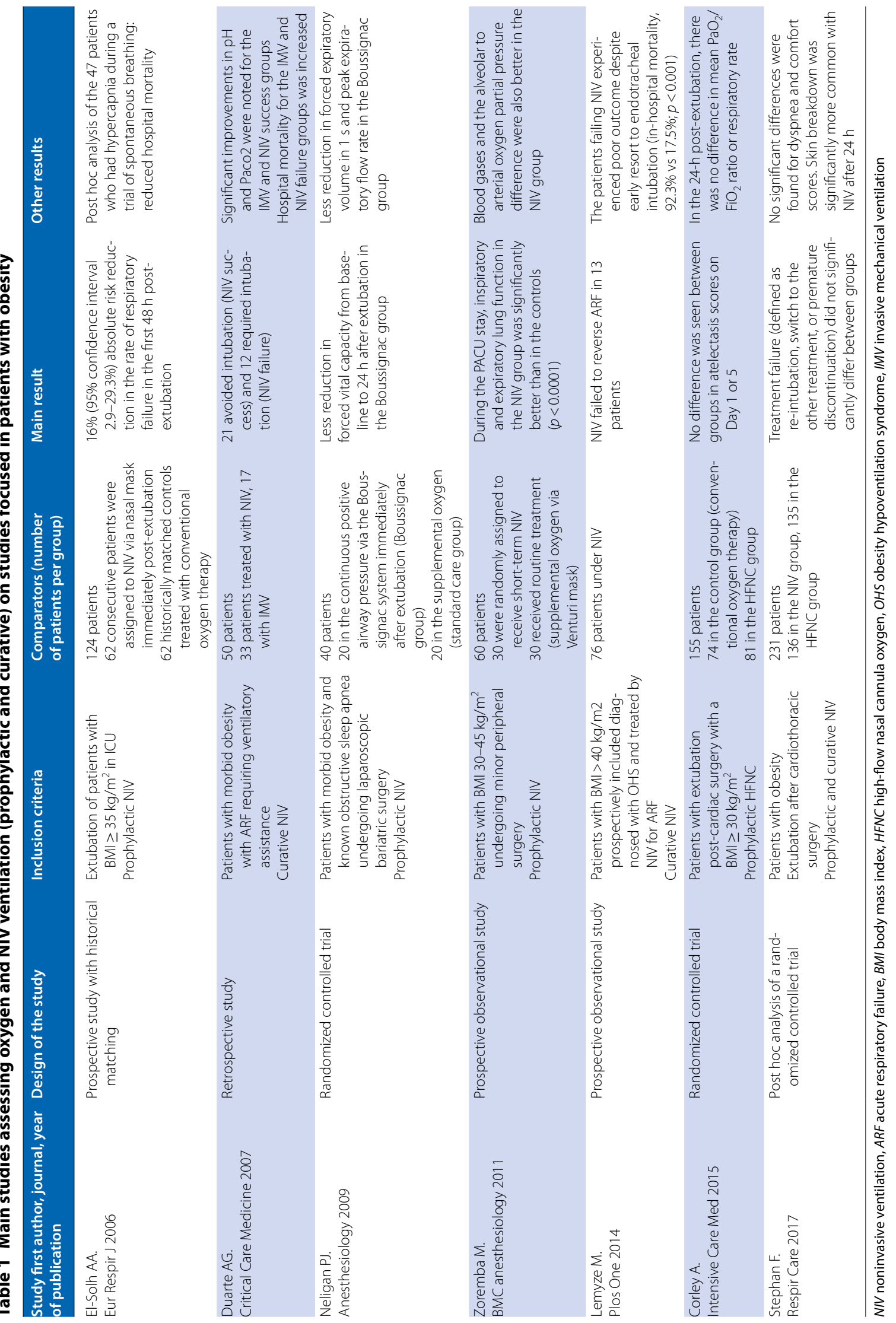


OHS patients [40]. Similarly, NIV is the usual treatment applied in OHS exacerbation, but no trial has evaluated its benefit as compared to other oxygen strategies. NIV brings together potentially beneficial physiological effects, including PEEP preserving upper airway patency and pressure support to control central hypoventilation. However, an observational study including 33 severely patients with obesity reports a lower BMI $\left(47 \mathrm{~kg} / \mathrm{m}^{2}\right)$ in patients with NIV success versus $62 \mathrm{~kg} / \mathrm{m}^{2}$ in those who failed NIV [26]. In this setting, NIV may be an appropriate treatment, but HFNC interspaced between NIV sessions should be evaluated.

\section{Airway management}

In addition to the pathophysiological modification of the respiratory system discussed above, patients with obesity have peculiar morphological alterations potentially associated with difficulties during mask ventilation and airway management: reduced neck mobility, limited mouth opening, increased size of pharyngeal and glossal soft tissues, unfavorable conformation and positioning of the larynx, increased neck circumference and decreased thyromental distance [41]. Moreover, patients with obesity have a high incidence of obstructive sleep apnea [42], which is directly related to many of the complications occurring during airway management of this sub-population of critically ill patients [43]. Obesity contributes to airway compression through increased airway fat deposits [44], and placing the patient with obesity recumbent may lead to sudden death [36]. It is very important to encourage upright positioning and avoid supine positioning. Overall, obesity, especially super obesity (BMI $\left.\geq 40 \mathrm{~kg} / \mathrm{m}^{2}\right)$ with android fat distribution, is an important risk factor for major complications, morbidity and mortality related to intubation procedures in the ICU [45].

Most of the literature existing on the airway management of patients with obesity is related to the operating room setting [46]. In this context, several strategies are often recommended, including the adoption of ramped position using specific devices or pillows/blankets under the patient's head and shoulder, pre-oxygenation with positive pressure ventilation [39] and the use of videolaryngoscopes [47]. However, compared to the elective surgical patient with obesity, the intubation of the critically ill patient has profound differences in indications, timing and co-existing conditions; therefore, caution should be applied when translating in the ICU the recommendations based on evidence in the operating room. In the ICU, the incidence of difficult intubation is double compared to the OR and the occurrence of severe complications is dramatically higher [46].
Pre-procedural patient preparation is key to successful intubation. An ideal preparation aims at prolonging timeto-desaturation, which in patients with obesity is mainly related to the rapid loss of FRC after sedation. Concerning positioning, a randomized controlled trial questioned the usefulness of the ramped position applied in critically ill patients [48]; however, the study included a large proportion of patients without obesity. Therefore, patient positioning should be individualized on the patient anatomy, based also on the intensivist's expertise. A semi-sitting position during pre-oxygenation could help to decrease positional flow limitation and air trapping [43]. Conventional bag-mask ventilation can result in rapid desaturation in patients with morbid obesity. Several studies confirmed that pre-oxygenation with CPAP or NIV improves oxygenation allowing a longer time window for intubation [39, 49]. For these reasons, positive pressure pre-oxygenation should be considered the reference in critically ill patients with obesity, considering that obesity carries an intrinsic increased risk for difficult mask ventilation. HFNC might also have a role [50], especially in rapid sequence intubation in non-severely hypoxemic patients, where avoidance of bag ventilation might be desirable but is associated with higher incidence of severe desaturation [51]. However, the value of HFNC value in patients with obesity must be clarified, and cannot replace a preoxygenation using positive pressure [52]. The intubation maneuver should be always considered as potentially difficult in patients with obesity [46], with older age, higher BMI, high Mallampati and MACOCHA scores and reduced neck mobility being independent risk factors for both difficult mask ventilation and intubation. A meta-analysis in surgical patients with obesity suggested an advantage of videolaryngoscopes over direct laryngoscopy [47]. In ICU patients with obesity, it seems reasonable to consider the use of videolaryngoscopes by adequately trained intensivists, especially in patients with several risk factors.

\section{Mechanical ventilation in non-ARDS patients Translated concepts from anesthesia to ICU}

Obesity is associated with abdominal and thoracic tissue mass, which transmit additional hydrostatic pressure via the chest wall and diaphragm to the pleural space and, thus, the alveoli. If pleural pressure is higher than intraalveolar pressure, the alveoli will collapse, and compression atelectasis will occur predominantly in dependent lung areas, where hydrostatic pressure is highest. For example, functional residual capacity is impaired by up to $21 \%$ in non-ventilated subjects with obesity in the supine position [18] and total lung and vital capacity are reduced as well. Induction of anesthesia with muscle relaxation 
following pre-oxygenation with $100 \% \mathrm{O}_{2}$ further reduces end-expiratory lung volume (EELV) by about $50 \%$, if a positive end-expiratory pressure (PEEP) of $5 \mathrm{cmH}_{2} \mathrm{O}$ is used after initiation of mechanical ventilation (Fig. 1) [18]. The main mechanism of gas exchange impairment is, therefore, shunt (atelectasis) in patients with obesity [24].

\section{Recruitment maneuver}

Because the opening pressure of alveoli is higher than the pressure needed to keep them open, application of an initial recruitment maneuver (RM) followed by adequate PEEP after intubation or disconnection of the patient from the ventilatory circuit seems intuitive. Due to the high pleural pressure in patients with obesity, opening pressures up to $50 \mathrm{cmH}_{2} \mathrm{O}$ applied during a $\mathrm{RM}$ in patients with obesity without lung injury may not result in full lung recruitment [53]. Potential side effects of applying such high airway pressures include a decrease in venous return and, thus, cardiac preload with a drop in cardiac output and systemic blood pressure. In addition, barotrauma such as pneumothorax or pneumomediastinum especially in patients with pre-existing structural lung damage such as emphysema, and a mechanically triggered boost of pre-existing lung inflammation may occur. Thus, RM is not generally recommended, and their use remains a decision based on individual risk/benefit considerations.

\section{PEEP}

In mechanically ventilated patients, PEEP is used to keep alveolar pressure above the closing pressure of alveoli thereby maintaining end-expiratory lung volume (EELV) and arterial oxygenation. In another words, PEEP does not strictly induce alveolar recruitment but PEEP avoids alveolar derecruitment by maintaining open alveoli. Thus, protective ventilation strategies may improve clinical outcomes even in patients without ARDS [54]. Due to the superimposed pressure transmitted by adipose tissue on the pleural space, closing pressures in patients with obesity are higher and lungs of these patients are more prone to such complications (Fig. 2). Despite these considerations, routinely used PEEP levels applied for ventilation of patients with obesity are often not higher than in normal weight patients [55]. In previous studies, different methods to find the individualized "best" PEEP in patients with obesity have been used. These approaches targeted improvements in oxygenation, lung mechanics, and regional ventilation distribution. In patients undergoing bariatric surgery, individualized PEEP resulted in a range of PEEP levels between 10 and $26 \mathrm{cmH}_{2} \mathrm{O}$ with a median of $18 \mathrm{cmH}_{2} \mathrm{O}$ [18] and restored EELV to the same level before intubation and initiation of mechanical ventilation. Other studies regularly found PEEP levels $>15 \mathrm{cmH}_{2} \mathrm{O}[56,57]$. However, a large trial of ventilation in patients with obesity during anesthesia did not demonstrate a difference in postoperative pulmonary complications for constant PEEP levels of 4 versus 12 $\mathrm{cmH}_{2} \mathrm{O}$ [58]. The PEEP levels in this pragmatic study, however, were not aiming at and resulting in full lung recruitment. As mentioned above, use of higher airway pressures is often associated with hemodynamic depression and higher requirements for fluids and vasopressors [58]. At least in the perioperative setting, evidence from meta-analyses and clinical trials are somewhat conflicting regarding improved clinical outcomes [54, 59].

\section{Tidal volume}

Limiting tidal volume $\left(V_{\mathrm{T}}\right)$ has been shown to reduce ventilation-associated lung injury and inflammation in non-selected patients with and without ARDS. The idea of normalizing $V_{\mathrm{T}}$ for predicted body weight (PBW) is based on the expected lung volume (dependent on patient's height and sex) and aims to limit the $V_{\mathrm{T}} / \mathrm{EELV}$ ratio, i.e., mechanical lung strain. As mentioned above, EELV is regularly below the values in a normal weight population. Thus, referencing $V_{\mathrm{T}}$ to $\mathrm{PBW}$ per se can result in higher strain than in normal weight patients. If PBW is not formally calculated but just estimated, there is a tendency to overestimate $\mathrm{PBW}$ and, thus, $V_{\mathrm{T}}$ in patients with obesity [55].

Positioning patients with obesity in ramped or sitting positions and even early mobilization may facilitate unloading the diaphragm from increased abdominal pressure and may thereby improve aeration of dependent lung areas. Early implementation of spontaneous breathing activity can preserve diaphragmatic tension, redistribute ventilation to dependent lung areas [60], may avoid diaphragmatic muscle atrophy caused by muscle relaxation [60] and reduce duration of mechanical ventilation [61].

\section{Mechanical ventilation in ARDS patients}

Anzueto et al. [62] and Karla et al. [63] showed that ARDS patients with obesity were ventilated with higher $V_{\mathrm{T}}$ (per kg of PBW) compared to ARDS patients without obesity.

It is tempting to speculate that the amount of atelectasis was different between patients with and without obesity and that the higher $V_{\mathrm{T}}$ was chosen by the clinicians to maintain an adequate alveolar ventilation. A study by Grasso et al. [64] tempted to confirm this hypothesis by reporting a decrease in the use of extracorporeal membrane oxygenation (ECMO) in patients with abdominal hypertension by increasing the airway pressure-often 


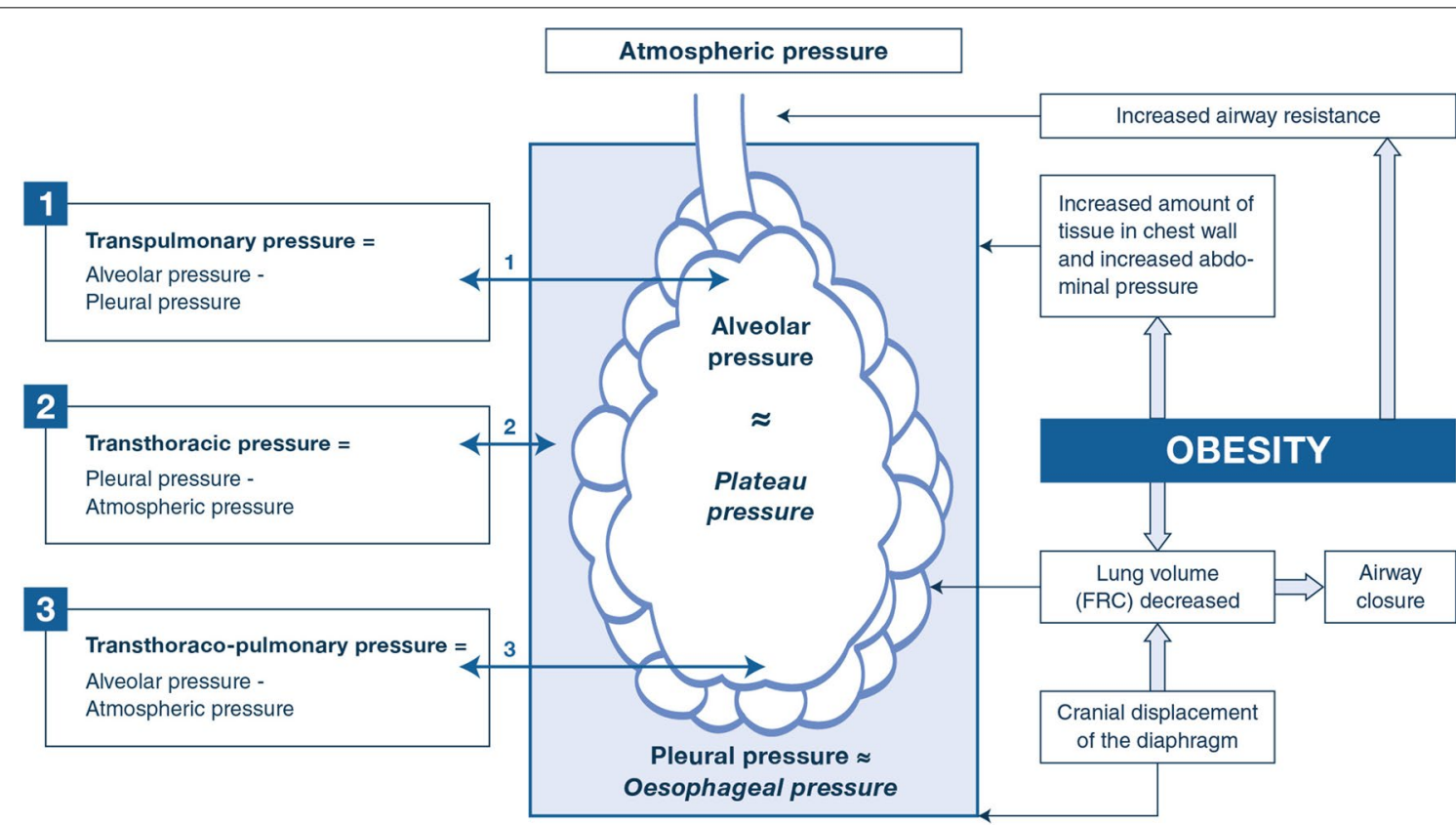

Fig. 2 Effect of obesity in main pressures of the respiratory system. The respiratory system includes the lung and the chest wall, and the airway pressure is related to both transpulmonary and transthoracic pressures, which differ in the patient with obesity compared to the patient without obesity. The relative part of pressure due to transthoracic pressure is often higher in the patient with obesity than in the patient without obesity (elevated pleural pressure, which can be estimated by esophageal pressure). The plateau pressure represents the pressure used to distend the chest wall plus lungs. In patients with obesity, elevated plateau pressure may be related to an elevated transthoracic pressure, and not an increase in transpulmonary pressure with lung overdistension. FRC functional residual capacity

above $30 \mathrm{cmH}_{2} \mathrm{O}$-based on a transpulmonary pressure target. Interestingly, in the study by Karla et al. [63], the airway plateau pressure and driving pressure were similar between patients with and without obesity. Of note, in both studies, the outcome was similar between the two groups. Similarly, De Jong et al. [65], in ARDS patients with obesity did not find any difference in driving pressure between survivors and non survivors [66].

When 21 ARDS patients with obesity were compared to 44 patients with ARDS but with a normal BMI, it was found that the two groups had similar recruitability and changes in oxygenation when PEEP was increased from 5 to $15 \mathrm{cmH}_{2} \mathrm{O}$ [67]. In these two groups, abdominal pressure and chest wall elastance were also similar. In contrast, Fumagalli et al. [68] found an impressive improvement in oxygenation and lung elastance using higher PEEP $\left(22 \mathrm{cmH}_{2} \mathrm{O}\right)$ compared to lower PEEP (13 $\mathrm{cmH}_{2} \mathrm{O}$ ). The higher PEEP was selected according to transpulmonary pressure, while the lower PEEP was selected according to a $\mathrm{PEEP} / \mathrm{FiO}_{2}$ table. Once again, the abdominal pressure was not measured (or reported). The same authors in a retrospective study of patients with severe ARDS found better gas exchange, respiratory mechanics, and survival in 50 patients treated according to a personalized approach (based on transpulmonary pressure) compared to 70 patients treated with a standard protocol [69]. The personalized approach resulted in much higher PEEP levels of $20 \mathrm{cmH}_{2} \mathrm{O}$ compared to $9 \mathrm{cmH}_{2} \mathrm{O}$ used in the standard approach. A retrospective analysis of the ALVEOLI trial showed improved outcome using PEEP $12 \mathrm{cmH}_{2} \mathrm{O}$ compared to $9 \mathrm{cmH}_{2} \mathrm{O}$ [70]. In this trial, however, patients with a weight $>1 \mathrm{~kg} / \mathrm{cm}$ of height and BMI usually $>50 \mathrm{~kg} / \mathrm{m}^{2}$ were not included.

We may wonder why the reported effect of different levels of PEEP differs among studies. We have to note that the BMI of the population of the different studies was $31 \mathrm{~kg} /$ $\mathrm{m}^{2}$, as in the study of Chiumello et al. [67] and likely in the ALVEOLI study [70], versus a BMI higher than $50 \mathrm{~kg} / \mathrm{m}^{2}$ in the study by Fumagalli et al. [68]. Given such a different $\mathrm{BMI}$, it is likely that the abdominal pressure and mechanical impairment were different in the different populations. The normalized mechanical power, that has been shown being strongly associated with mortality [71], was not monitored. Moreover, RM was not consistently used, and their use and timing remain a matter of debate in ARDS patients with and without obesity [72]. A PEEP decremental trial preceded by a RM may decrease lung overdistension and collapse in ARDS obese patients [73]. In 21 ARDS patients with severe obesity (BMI $=57 \pm 12 \mathrm{~kg} /$ $\mathrm{m}^{2}$ ) [74], RM was performed during pressure controlled 
ventilation with delta pressure of $10 \mathrm{cmH}_{2} \mathrm{O}$, PEEP was increased until a plateau pressure of $50 \mathrm{cmH}_{2} \mathrm{O}$ for $1 \mathrm{~min}$. After, the ventilator mode was switched to volume controlled ventilation $(5 \mathrm{ml} / \mathrm{kg}$ of $\mathrm{PBW})$, and the PEEP dropped by $2 \mathrm{cmH}_{2} \mathrm{O}$ every $30 \mathrm{~s}$. The optimal PEEP was determined by the PEEP value with the best compliance of the respiratory system plus $2 \mathrm{cmH}_{2} \mathrm{O}$. Finally, a second lung RM was performed and the selected optimal PEEP was set. Required PEEP was increased to $8[7,10] \mathrm{cmH}_{2} \mathrm{O}$ above traditional ARDSnet settings with improvement of lung function, oxygenation and ventilation/perfusion matching, without impairment of hemodynamics or right heart function. Moreover, in a retrospective study [69], the same authors also reported that patients treated with RM and with higher PEEP were weaned from vasopressors agents faster (and improved survival) than patients who were treated with low ARDSnet PEEP table. Future investigations would be beneficial to clarify the lungheart interaction when high airway pressure is used in the settings of high pleural pressure.

Given that the setting of mechanical ventilation $\left(V_{\mathrm{T}}\right.$, PEEP) and the indicators of ventilator-induced lung injury (mechanical power, driving pressure) are crucially dependent on chest wall elastance, it is our opinion that it is difficult to propose any treatment if key variables such as transpulmonary pressure and intra-abdominal pressure are not measured or ignored (Fig. 2).

Prone position [75] also deserves attention in patients with ARDS and obesity. The safety and efficiency of this therapeutic were similar between patients with and without obesity, and the ratio of alveolar pressure in oxygen over fraction of inspired oxygen $\left(\mathrm{PaO}_{2} / \mathrm{FiO}_{2}\right)$ was significantly more increased after prone position in patients with obesity compared to patients without obesity [76]. Prone position is a therapeutic of choice in patients with severe ARDS and obesity, and the mechanisms of action, caution and clinical effects are detailed in Fig. 3. In case of severe ARDS after failure or inability to use prone positioning and neuromuscular blockers, veno-venous extracorporeal membrane oxygenation (ECMO) can also be safely used in ARDS obese patients [77, 78].

\section{Weaning and extubation}

The spontaneous breathing trial should be clearly separated from the level of pressure support and PEEP set before extubation and the respiratory support following extubation. A physiological study specifically assessed the inspiratory effort during weaning of mechanical ventilation in critically ill patients with morbid obesity [79]. The main result of this study was that for patients with obesity, T-piece and pressure support ventilation $0+$ PEEP $0 \mathrm{cmH}_{2} \mathrm{O}$ were the weaning tests predicting post-extubation inspiratory effort and work of breathing the most accurately [79]. If the work of breathing is closely the same between T-Tube and after extubation [79], the patient with obesity remains prone to atelectasis, and therefore, atelectases should be avoided as much as possible. That is $\mathrm{s}$ why after a $\mathrm{T}$-tube, the obese patient should be reconnected to mechanical ventilation, as already demonstrated in patients without obesity [80], and put again under pressure support with sufficient PEEP and pressure support. Similarly, following extubation, as detailed below, preventing atelectasis has to start as soon as possible, using CPAP or NIV.

Moreover, to perform extubation as soon as possible, sedation should be stopped as early as possible and benzodiazepines avoided, even more than in patients without obesity due to prolonged release of drugs in patients with obesity [81].

Prophylactic NIV after extubation decreases the risk of ARF by $16 \%$ and length of ICU stay [82]. In hypercapnic ICU patients with obesity, using NIV after extubation is associated with decreased mortality [82]. A randomized controlled trial performed in patients with morbid obesity undergoing bariatric surgery found an improvement of ventilatory function when CPAP was implemented immediately after extubation as compared to CPAP started 30 min after extubation [83] (Table 1). In case of positive pressure therapy already used at home, it should be reintroduced as early as possible in the ICU as soon as higher levels of assistance requiring the use of an ICU ventilator are no longer needed. Home positive pressure therapy could also be introduced in ICU for selected patients with obesity. CPAP is indicated for use in patients with severe obstructive sleep apnea syndrome, as first-line therapy in these indications. In the case of combined obstructive apnea syndrome and moderate hypercapnia between 45 and $55 \mathrm{mmHg}$, a CPAP device will be offered as first-line therapy, and a NIV device, allowing ventilation at 2 pressure levels, will be offered in case of failure. If there is a history of respiratory decompensation with acute hypercapnic respiratory failure, hypercapnia greater than $55 \mathrm{mmHg}$ and/or no associated obstructive sleep apnea syndrome, a NIV device will be offered [84].

HFNC was not found to be superior to standard oxygen to prevent extubation failure in 155 post-cardiac surgery patients with obesity [85]. Among cardiothoracic surgery subjects with obesity with or without respiratory failure, the use of continuous HFNC compared to NIV did not result in a worse rate of treatment failure [33] (Table 1). Similarly, in the study by Hernandez et al. [86] including $20 \%$ of patients with obesity, among high-risk adults who have undergone extubation, preventive HFNC was not inferior to preventive NIV for reducing reintubation rate and postextubation respiratory failure. In a randomized controlled trial of the same team comparing HFNC 


\section{PRONE POSITIONING OF ARDS PATIENTS WITH OBESITY}

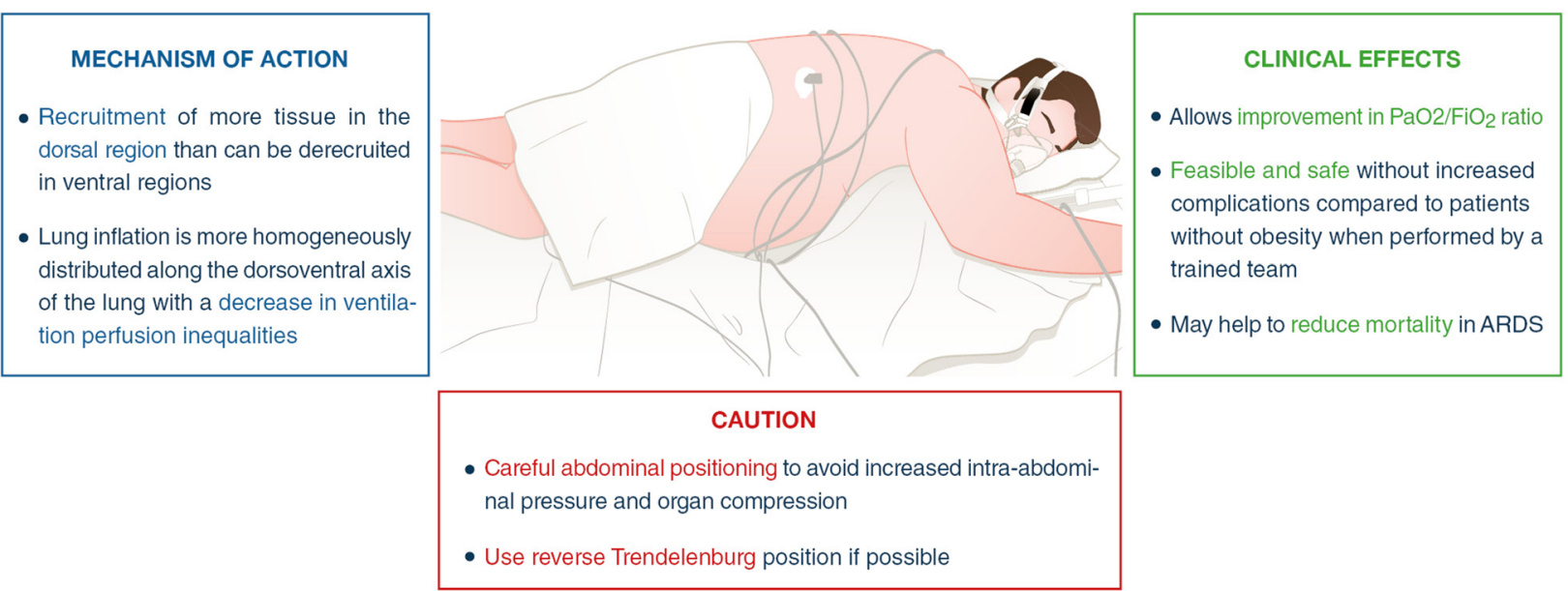

Fig. 3 Prone positioning in patients with obesity. ARDS acute respiratory distress syndrome. $\mathrm{PaO}_{2} / \mathrm{FiO}_{2}$ pressure of arterial oxygen to fractional inspired oxygen concentration

to standard oxygen [87] in high-risk non-hypercapnic patients including $22 \%$ of patients with obesity, the study was stopped due to low recruitment after 155 patients, without any difference in extubation failure rate found between the two groups.

The specificities of weaning and extubation in ICU patients with obesity are summarized in Supplemental Table 1. A summary of the main respiratory physiological modifications and some suggestions for mechanical ventilation in critically ill patients with obesity are proposed in Fig. 4.

\section{Obesity paradox}

In the general population, obesity is one of the top 10 risk factors of chronic diseases and a risk factor for death. Consistent with this trend in the general population, the number of obese patients admitted to the ICU is rapidly increasing [88]. Obesity decreases life expectancy in the population, and obesity in childhood is now a healthcare crisis for our next generation with unknown consequences. There are overwhelming scientific data on overall mortality/morbidity, the healthcare system shortcomings to deliver adequate care, and the social discrimination and injustice that individuals with obesity are subject on daily basis. However, in ICU, patients with obesity may be more likely to develop ARDS, but their survival sometimes appeared to be better, a phenomenon called the 'obesity paradox' [89]. Patients with obesity have immunological and pulmonary mechanics differences compared to patients without obesity detailed in the supplemental content (see Supplemental content 1).
These differences are increased for patients with higher level of obesity.

Furthermore, clinicians may overestimate the lung size of patients with obesity, by considering real instead of PBW, and use higher $V_{\mathrm{T}}$ during mechanical ventilation, risking ventilator-induced lung injury. The mentioned patient factors may also cause respiratory muscle fatigue and difficult weaning. Indeed, 2 meta-analyses show that in close to 200,000 ARDS patients, obesity is linked to a higher risk of developing ARDS and patients with obesity need mechanical ventilation for a longer period of time, compared to critically ill patients without obesity $[13,16]$. As a consequence, ICU-length of stay is also prolonged in patients with obesity, while hospital length of stay is not $[13,16]$. While patients with obesity are on mechanical ventilation for a longer period of time, these meta-analyses also demonstrate a survival advantage for patients with obesity. This observation is coined the 'obesity paradox' as a survival benefit may appear counterintuitive in view of the detrimental alterations in respiratory function as described above. Several reasons to explain the obesity paradox in ARDS patients with obesity have been put forward. Apart from the described immunological differences, patients with obesity have more metabolic reserve and may, therefore, tolerate the catabolic stress of critical illness during ARDS better, because of energy stores in the form of adipose tissue.

It is important to also address the possibility that patients with obesity may have a lower threshold for ICU admission, e.g., because of the need of more nursing staff not available on the ward or monitoring purposes. This 
would mean that patients with obesity admitted to the ICU are less sick and therefore may show a better survival because of selection bias, not representing a real phenomenon. As in the meta-analyses, adjustments for covariates like disease severity were not possible; this may appear plausible. In a large study in over 150,000 ICU patients, however, the obesity paradox remained present even when adjusted for several covariates including disease severity [90]. Also, patients with obesity may have been misclassified as ARDS if atelectasis is interpreted as bilateral infiltrates. Using a causal inference approach to reduce residual confounding bias due to missing data, it was found that the survival of patients without obesity would not have been improved if they had obesity [91], findings which question the obesity paradox.

\section{Conclusion}

In summary, patients with obesity are more likely to develop respiratory complications, including ARF and ARDS. Considering some physiological studies, for non-invasive management, using NIV has to be considered both for preventing and treating ARF, even if the level of proof is low, especially in comparison with HFNC. Airway management in critically ill patients with obesity poses specific challenges, and adequate patient evaluation, pre-oxygenation and choice of intubation devices might improve outcomes. After intubation procedure for invasive mechanical ventilation, patients with obesity being more prone to lung collapse require higher PEEP to avoid it. Low $V_{\mathrm{T}}$ according to PBW should be used both in non-ARDS and ARDS

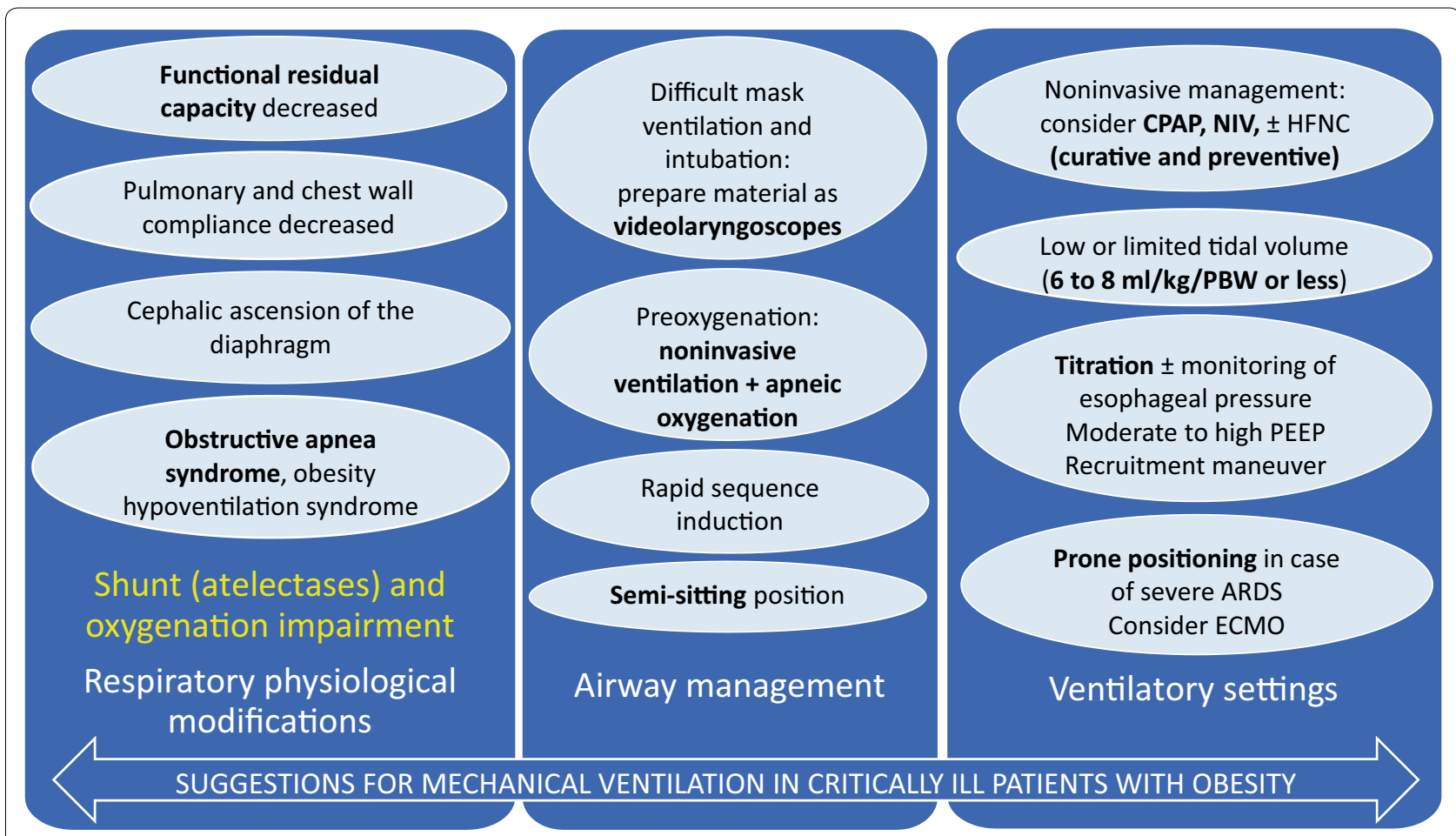

Fig. 4 Main respiratory physiological modifications and suggestions for mechanical ventilation in critically ill patients with obesity. The main respiratory physiological modifications (functional residual capacity decreased, abdominal pressure often increased, pulmonary and chest wall compliance often decreased, cephalic ascension of diaphragm, oxygen consumption and work of breathing increased) lead to shunt via atelectasis and gas exchange impairment. Comorbidities are often associated with obesity: obstructive apnea syndrome and obesity hypoventilation syndrome. Consequences on airway management, potentially difficult, include the preparation of adequate material for difficult intubation as videolaryngoscopes, preoxygenation with noninvasive ventilation in a semi-sitting position, considering adding apneic oxygenation (OPTINIV method), rapid sequence induction and recruitment maneuver following intubation after hemodynamic stabilization. Ventilatory settings include low or limited tidal volume $\left(6-8 \mathrm{ml} / \mathrm{kg} / \mathrm{PBW}\right.$ or less), moderate to high PEEP $\left(7-20 \mathrm{cmH}_{2} \mathrm{O}\right)$ if hemodynamically well tolerated, recruitment maneuver (if hemodynamically well tolerated, in selected patients), monitoring of esophageal pressure if possible, use of prone positioning in a trained team in case of severe ARDS, without contra-indicating ECMO. After extubation, CPAP or NIV should be considered early, as implementation of positive pressure therapies at home after evaluation. PBW predicted body weight, PEEP positive end-expiratory pressure, ARDS acute respiratory distress syndrome, ECMO extracorporeal membrane oxygenation, CPAP continuous positive airway pressure, NIV noninvasive ventilation, HFNC high-flow nasal cannula oxygen 
patients. RM is not systematically recommended, and their use remains a decision based on individual risk/ benefit considerations. Prone positioning should be used in severe ARDS patients with obesity.

\section{Electronic supplementary material}

The online version of this article (https://doi.org/10.1007/s00134-020-06286-x) contains supplementary material, which is available to authorized users.

\section{Author details}

${ }^{1}$ Research Unit: PhyMedExp, INSERM U-1046, CNRS, Anesthesia and Critical Care Department (DAR-B), Saint Eloi, University of Montpellier, 34295 Montpellier, cedex 5, France. ${ }^{2}$ Department of Anaesthesiology, Intensive Care and Emergency Medicine, Pain Therapy, Bergmannstrost Hospital Halle, 06112 Halle, Germany. ${ }^{3}$ Department of Anaesthesiology and Intensive Care, University of Leipzig Medical Centre, 04103 Leipzig, Germany. ${ }^{4}$ Integrated Research and Treatment Centre (IFB) Adiposity Diseases, University of Leipzig, 04103 Leipzig, Germany. ${ }^{5}$ Department of Medical Sciences, Clinical Physiology, Uppsala University, Uppsala, Sweden. ${ }^{6}$ SC Anestesia e Rianimazione, Ospedale San Paolo-Polo Universitario, ASST Santi Paolo e Carlo, Milan, Italy. ${ }^{7}$ Dipartimento di Scienze della Salute, Università degli Studi di Milano, Milan Italy. ${ }^{8}$ Centro ricerca coordinata di insufficienza respiratoria, Milan, Italy. ${ }^{9} \mathrm{CHU}$ de Poitiers, Médecine Intensive Réanimation, Poitiers, France. ${ }^{10}$ INSERM CIC 1402-ALIVE, Université de Poitiers, Faculté de Médecine et Pharmacie, Poitiers, France. ${ }^{11}$ Department of Surgical Sciences and Integrated Diagnostics, University of Genoa, Genoa, Italy. ${ }^{12}$ Anaesthesia and Intensive Care, IRCCS San Martino Policlinico Hospital, 16131 Genoa, Italy. ${ }^{13}$ Division of Cellular and Molecular Medicine, Clinical Department and Laboratory of Intensive Care Medicine, KU Leuven University, Herestraat 49, 3000 Leuven, Belgium.

${ }^{14}$ Department Intensive Care Medicine, Center of Infectious Diseases, Radboudumc, Nijmegen, The Netherlands.

\section{Compliance with ethical standards}

\section{Conflicts of interest}

SJ reports receiving consulting fees from Drager, Medtronic, Fresenius, Baxter and Fisher \& Paykel. HW reports receiving consulting fees from Liberate Medical, MSD, InfectoPharm and Dräger. No potential conflict of interest relevant to this article was reported for the other authors.

\section{Publisher's Note}

Springer Nature remains neutral with regard to jurisdictional claims in published maps and institutional affiliations.

Received: 21 September 2020 Accepted: 6 October 2020

Published online: 23 October 2020

\section{References}

1. Global BMIMC, Di Angelantonio E, Bhupathiraju ShN, Wormser D, Gao P, Kaptoge S, Berrington de Gonzalez A, Cairns BJ, Huxley R, Jackson ChL, Joshy G, Lewington S, Manson JE, Murphy N, Patel AV, Samet JM, Woodward M, Zheng W, Zhou M, Bansal N, Barricarte A, Carter B, Cerhan JR, Smith GD, Fang X, Franco OH, Green J, Halsey J, Hildebrand JS, Jung KJ, Korda RJ, McLerran DF, Moore SC, O'Keeffe LM, Paige E, Ramond A, Reeves GK, Rolland B, Sacerdote C, Sattar N, Sofianopoulou E, Stevens J, Thun M, Ueshima H, Yang L, Yun YD, Willeit P, Banks E, Beral V, Chen Z, Gapstur SM, Gunter MJ, Hartge P, Jee SH, Lam TH, Peto R, Potter JD, Willett WC, Thompson SG, Danesh J, Hu FB (2016) Body-mass index and all-cause mortality: individual-participant-data meta-analysis of 239 prospective studies in four continents. Lancet 388:776-786

2. Ward ZJ, Bleich SN, Cradock AL, Barrett JL, Giles CM, Flax C, Long MW, Gortmaker SL (2019) Projected US state-level prevalence of adult obesity and severe obesity. N Engl J Med 381:2440-2450

3. Schetz M, De Jong A, Deane AM, Druml W, Hemelaar P, Pelosi P, Pickkers P, Reintam-Blaser A, Roberts J, Sakr Y, Jaber S (2019) Obesity in the critically ill: a narrative review. Intensive Care Med 45:757-769
4. Bell T, Stokes S, Jenkins PC, Hatcher L, Fecher AM (2017) Prevalence of cardiovascular and respiratory complications following trauma in patients with obesity. Heart Lung J Crit Care 46:347-350

5. Cone JT, Benjamin ER, Alfson DB, Demetriades D (2020) Isolated severe blunt traumatic brain injury: effect of obesity on outcomes. J Neurosurg 12:1-8. https://doi.org/10.3171/2020.3.JNS193458

6. Aoki M, Hagiwara S, Oshima K, Suzuki M, Sakurai A, Tahara Y, Nagao K, Yonemoto N, Yaguchi A, Morimura N (2018) Obesity was associated with worse neurological outcome among Japanese patients with out-ofhospital cardiac arrest. Intensive Care Med 44:665-666

7. Fezeu L, Julia C, Henegar A, Bitu J, Hu FB, Grobbee DE, Kengne AP, Hercberg S, Czernichow S (2011) Obesity is associated with higher risk of intensive care unit admission and death in influenza A (H1N1) patients: a systematic review and meta-analysis. Obes Rev 12:653-659

8. Zhou Y, Yang Q, Chi J, Dong B, Lv W, Shen L, Wang Y (2020) Comorbidities and the risk of severe or fatal outcomes associated with coronavirus disease 2019: a systematic review and meta-analysis. Int J Infect Dis 99:47-56

9. Azoulay E, Fartoukh M, Darmon M, Géri G, Voiriot G, Dupont T, Zafrani L, Girodias L, Labbé V, Dres M, Beurton A, Vieillard-Baron A, Demoule A (2020) Increased mortality in patients with severe SARS-CoV-2 infection admitted within seven days of disease onset. Intensive Care Med 46:1714-1722

10. Rottoli M, Bernante P, Belvedere A, Balsamo F, Garelli S, Giannella M, Cascavilla A, Tedeschi S, lanniruberto S, Rosselli Del Turco E, Tonetti T, Ranieri VM, Poggioli G, Manzoli L, Pagotto U, Viale P, Bartoletti M (2020) How important is obesity as a risk factor for respiratory failure, intensive care admission and death in hospitalised COVID-19 patients? Results from a single Italian centre. Eur J Endocrinol 183:389-397

11. Lemyze M, Courageux N, Maladobry T, Arumadura C, Pauquet P, Orfi A, Komorowski M, Mallat J, Granier M (2020) Implications of obesity for the management of severe coronavirus disease 2019 pneumonia. Crit Care Med 48:e761-e767

12. Petersen A, Bressem K, Albrecht J, Thie HM, Vahldiek J, Hamm B, Makowsk MR, Niehues A, Niehues SM, Adams LC (2020) The role of visceral adiposity in the severity of COVID-19: highlights from a unicenter cross-sectional pilot study in Germany. Metab Clin Exp 110:154317

13. Zhi G, Xin W, Ying W, Guohong X, Shuying L (2016) "Obesity Paradox" in acute respiratory distress syndrome: asystematic review and meta-analysis. PLoS ONE 11:e0163677

14. Dobner J, Kaser S (2018) Body mass index and the risk of infection -from underweight to obesity. Clin Microbiol Infect Off Publ Eur Soc Clin Microbiol Infect Dis 24:24-28

15. Green WD, Beck MA (2017) Obesity altered T cell metabolism and the response to infection. Curr Opin Immunol 46:1-7

16. Zhao Y, Li Z, Yang T, Wang M, Xi X (2018) Is body mass index associated with outcomes of mechanically ventilated adult patients in intensive critical units? A systematic review and meta-analysis. PLoS ONE 13:e0198669

17. Jones RL, Nzekwu MM (2006) The effects of body mass index on lung volumes. Chest 130:827-833

18. Nestler C, Simon P, Petroff D, Hammermuller S, Kamrath D, Wolf S, Dietrich A, Camilo LM, Beda A, Carvalho AR, Giannella-Neto A, Reske AW, Wrigge H (2017) Individualized positive end-expiratory pressure in obese patients during general anaesthesia: a randomized controlled clinical trial using electrical impedance tomography. Br J Anaesth 119:1194-1205

19. Salome CM, King GG, Berend N (2010) Physiology of obesity and effects on lung function. J Appl Physiol (1985) 108:206-211

20. Pelosi P, Croci M, Ravagnan I, Tredici S, Pedoto A, Lissoni A, Gattinoni L (1998) The effects of body mass on lung volumes, respiratory mechanics, and gas exchange during general anesthesia. Anesth Analg 87:654-660

21. Grieco DL, Anzellotti GM, Russo A, Bongiovanni F, Costantini B, D'Indinosante M, Varone F, Cavallaro F, Tortorella L, Polidori L, Romano B, Gallotta V, Dell'Anna AM, Sollazzi L, Scambia G, Conti G, Antonelli M (2019) Airway closure during surgical pneumoperitoneum in obese patients. Anesthesiology 131:58-73

22. Hedenstierna G, Chen L, Brochard L (2020) Airway closure, more harmful than atelectasis in intensive care? Intensive Care Med. https://doi. org/10.1007/s00134-020-06144-w

23. Hedenstierna G, Rothen HU (2012) Respiratory function during anesthesia: effects on gas exchange. Compr Physiol 2:69-96 
24. Hedenstierna G, Tokics L, Scaramuzzo G, Rothen HU, Edmark L, Öhrvik J (2019) Oxygenation impairment during anesthesia: influence of age and body weight. Anesthesiology 131:46-57

25. Frat JP, Gissot V, Ragot S, Desachy A, Runge I, Lebert C, Robert R (2008) Impact of obesity in mechanically ventilated patients: a prospective study. Intensive Care Med 34:1991-1998

26. Duarte AG, Justino E, Bigler T, Grady J (2007) Outcomes of morbidly obese patients requiring mechanical ventilation for acute respiratory failure. Crit Care Med 35:732-737

27. Kress JP, Pohlman AS, Alverdy J, Hall JB (1999) The impact of morbid obesity on oxygen cost of breathing (VO(2RESP)) at rest. Am J Respir Crit Care Med 160:883-886

28. Lemyze M, Mallat J, Duhamel A, Pepy F, Gasan G, Barrailler S, Vangrunderbeeck N, Tronchon L, Thevenin D (2013) Effects of sitting position and applied positive end-expiratory pressure on respiratory mechanics of critically ill obese patients receiving mechanical ventilation. Crit Care Med 41:2592-2599

29. Perilli V, Sollazzi L, Bozza P, Modesti C, Chierichini A, Tacchino RM, Ranieri $R$ (2000) The effects of the reverse trendelenburg position on respiratory mechanics and blood gases in morbidly obese patients during bariatric surgery. Anesth Analg 91:1520-1525

30. Rochwerg B, Brochard L, Elliott MW, Hess D, Hill NS, Nava S, Navalesi PMOTSC, Antonelli M, Brozek J, Conti G, Ferrer M, Guntupalli K, Jaber S, Keenan S, Mancebo J, Mehta S, Raoof SMOTTF (2017) Official ERS/ATS clinical practice guidelines: noninvasive ventilation for acute respiratory failure. Eur Respir J 50(2):1602426. https://doi.org/10.1183/13993 003.02426-2016

31. Jaber $S$, Lescot T, Futier E, Paugam-Burtz C, Seguin P, Ferrandiere M, Lasocki S, Mimoz O, Hengy B, Sannini A, Pottecher J, Abback PS, Riu B, Belafia F, Constantin JM, Masseret E, Beaussier M, Verzilli D, De Jong A, Chanques G, Brochard L, Molinari N (2016) Effect of noninvasive ventilation on tracheal reintubation among patients with hypoxemic respiratory failure following abdominal surgery: a randomized clinical trial. JAMA 315:1345-1353

32. Jaber S, Delay JM, Chanques G, Sebbane M, Jacquet E, Souche B, Perrigault PF, Eledjam JJ (2005) Outcomes of patients with acute respiratory failure after abdominal surgery treated with noninvasive positive pressure ventilation. Chest 128:2688-2695

33. Stephan F, Berard L, Rezaiguia-Delclaux S, Amaru P (2017) High-flow nasal cannula therapy versus intermittent noninvasive ventilation in obese subjects after cardiothoracic surgery. Respir Care 62:1193-1202

34. Leone M, Einav S, Chiumello D, Constantin JM, De Robertis E, De Abreu MG, Gregoretti C, Jaber S, Maggiore SM, Pelosi P, Sorbello M, Afshari A (2020) Noninvasive respiratory support in the hypoxaemic peri-operative/periprocedural patient: a joint ESA/ESICM guideline. Intensive Care Med 46:697-713

35. Ricard JD, Roca O, Lemiale V, Corley A, Braunlich J, Jones P, Kang BJ, Lellouche F, Nava S, Rittayamai N, Spoletini G, Jaber S, Hernandez G (2020) Use of nasal high flow oxygen during acute respiratory failure. Intensive Care Med. https://doi.org/10.1007/s00134-020-06228-7

36. Pepin JL, Timsit JF, Tamisier R, Borel JC, Levy P, Jaber S (2016) Prevention and care of respiratory failure in obese patients. Lancet Respir Med 4:407-418

37. Frat JP, Thille AW, Mercat A, Girault $C$, Ragot $S$, Perbet $S$, Prat G, Boulain T, Morawiec E, Cottereau A, Devaquet J, Nseir S, Razazi K, Mira JP, Argaud L, Chakarian JC, Ricard JD, Wittebole X, Chevalier S, Herbland A, Fartoukh M, Constantin JM, Tonnelier JM, Pierrot M, Mathonnet A, Beduneau G, Deletage-Metreau C, Richard JC, Brochard L, Robert R (2015) High-flow oxygen through nasal cannula in acute hypoxemic respiratory failure. $\mathrm{N}$ Engl J Med 372:2185-2196

38. Lemyze M, Taufour P, Duhamel A, Temime J, Nigeon O, Vangrunderbeeck N, Barrailler S, Gasan G, Pepy F, Thevenin D, Mallat J (2014) Determinants of noninvasive ventilation success or failure in morbidly obese patients in acute respiratory failure. PLoS ONE 9:e97563

39. Futier E, Constantin JM, Pelosi P, Chanques G, Massone A, Petit A, Kwiatkowski F, Bazin JE, Jaber S (2011) Noninvasive ventilation and alveolar recruitment maneuver improve respiratory function during and after intubation of morbidly obese patients: a randomized controlled study. Anesthesiology 114:1354-1363

40. Mokhlesi B, Masa JF, Brozek JL, Gurubhagavatula I, Murphy PB, Piper AJ, Tulaimat A, Afshar M, Balachandran JS, Dweik RA, Grunstein RR, Hart N,
Kaw R, Lorenzi-Filho G, Pamidi S, Patel BK, Patil SP, Pépin JL, Soghier I, Tamae Kakazu M, Teodorescu M (2019) Evaluation and management of obesity hypoventilation syndrome. an official American thoracic society clinical practice guideline. Am J Respir Crit Care Med 200:e6-e24

41. Carron M, Safaee Fakhr B, leppariello G, Foletto M (2020) Perioperative care of the obese patient. Br J Surg 107:e39-e55

42. Hodgson LE, Murphy PB, Hart N (2015) Respiratory management of the obese patient undergoing surgery. J Thorac Dis 7:943-952

43. De Jong A, Chanques G, Jaber S (2017) Mechanical ventilation in obese ICU patients: from intubation to extubation. Crit Care 21:63

44. Dempsey JA, Veasey SC, Morgan BJ, O'Donnell CP (2010) Pathophysiology of sleep apnea. Physiol Rev 90:47-112

45. De Jong A, Rolle A, Molinari N, Paugam-Burtz C, Constantin JM, Lefrant JY, Asehnoune K, Jung B, Futier E, Chanques G, Azoulay E, Jaber S (2018) Cardiac arrest and mortality related to intubation procedure in critically ill adult patients: a multicenter cohort study. Crit Care Med 46:532-539

46. De Jong A, Molinari N, Pouzeratte Y, Verzilli D, Chanques G, Jung B, Futier E, Perrigault PF, Colson P, Capdevila X, Jaber S (2015) Difficult intubation in obese patients: incidence, risk factors, and complications in the operating theatre and in intensive care units. Br J Anaesth 114:297-306

47. Hoshijima H, Denawa Y, Tominaga A, Nakamura C, Shiga T, Nagasaka H (2018) Videolaryngoscope versus Macintosh laryngoscope for tracheal intubation in adults with obesity: a systematic review and meta-analysis. J Clin Anesth 44:69-75

48. Semler MW, Janz DR, Russell DW, Casey JD, Lentz RJ, Zouk AN, deBoisblanc BP, Santanilla JI, Khan YA, Joffe AM, Stigler WS, Rice TW (2017) A multicenter, randomized trial of ramped position vs sniffing position during endotracheal intubation of critically ill adults. Chest 152:712-722

49. Gander S, Frascarolo P, Suter M, Spahn DR, Magnusson L (2005) Positive end-expiratory pressure during induction of general anesthesia increases duration of nonhypoxic apnea in morbidly obese patients. Anesth Analg 100:580-584

50. Guitton C, Ehrmann S, Volteau C, Colin G, Maamar A, Jean-Michel V, Mahe PJ, Landais M, Brule N, Bretonnière C, Zambon O, Vourc'h M (2019) Nasal high-flow preoxygenation for endotracheal intubation in the critically ill patient: a randomized clinical trial. Intensive Care Med 45:447-458

51. Casey JD, Janz DR, Russell DW, Vonderhaar DJ, Joffe AM, Dischert KM, Brown RM, Zouk AN, Gulati S, Heideman BE, Lester MG, Toporek AH, Bentov I, Self WH, Rice TW, Semler MW (2019) Bag-mask ventilation during tracheal intubation of critically ill adults. N Engl J Med 380:811-821

52. De Jong A, Casey JD, Myatra SN (2020) Focus on noninvasive respiratory support before and after mechanical ventilation in patients with acute respiratory failure. Intensive Care Med 46:1460-1463

53. Reinius $H$, Jonsson L, Gustafsson S, Sundbom M, Duvernoy O, Pelosi P, Hedenstierna G, Freden F (2009) Prevention of atelectasis in morbidly obese patients during general anesthesia and paralysis: a computerized tomography study. Anesthesiology 111:979-987

54. Serpa Neto A, Hemmes SN, Barbas CS, Beiderlinden M, Biehl M, Binnekade JM, Canet J, Fernandez-Bustamante A, Futier E, Gajic O, Hedenstierna G, Hollmann MW, Jaber S, Kozian A, Licker M, Lin WQ, Maslow AD, Memtsoudis SG, Reis Miranda D, Moine P, Ng T, Paparella D, Putensen C, Ranieri M, Scavonetto F, Schilling T, Schmid W, Selmo G, Severgnini P, Sprung J, Sundar S, Talmor D, Treschan T, Unzueta C, Weingarten TN, Wolthuis EK, Wrigge H, Gama de Abreu M, Pelosi P, Schultz MJ (2015) Protective versus conventional ventilation for surgery: a systematic review and individual patient data meta-analysis. Anesthesiology 123:66-78

55. Ball L, Hemmes SNT, Serpa Neto A, Bluth T, Canet J, Hiesmayr M, HolImann MW, Mills GH, Vidal Melo MF, Putensen C, Schmid W, Severgnini P, Wrigge H, Gama de Abreu M, Schultz MJ, Pelosi P (2018) Intraoperative ventilation settings and their associations with postoperative pulmonary complications in obese patients. Br J Anaesth 121:899-908

56. Tusman G, Groisman I, Fiolo FE, Scandurra A, Arca JM, Krumrick G, Bohm SH, Sipmann FS (2014) Noninvasive monitoring of lung recruitment maneuvers in morbidly obese patients: the role of pulse oximetry and volumetric capnography. Anesth Analg 118:137-144

57. Erlandsson K, Odenstedt H, Lundin S, Stenqvist O (2006) Positive endexpiratory pressure optimization using electric impedance tomography in morbidly obese patients during laparoscopic gastric bypass surgery. Acta Anaesthesiol Scand 50:833-839

58. Bluth T, Serpa Neto A, Schultz MJ, Pelosi P, Gama de Abreu M (2019) Effect of intraoperative high positive end-expiratory pressure (PEEP) 
with recruitment maneuvers vs low peep on postoperative pulmonary complications in obese patients: a randomized clinical trial. JAMA 321:2292-2305. https://doi.org/10.1001/jama.2019.7505

59. Futier E, Constantin JM, Paugam-Burtz C, Pascal J, Eurin M, Neuschwander A, Marret E, Beaussier M, Gutton C, Lefrant JY, Allaouchiche B, Verzilli D, Leone M, De Jong A, Bazin JE, Pereira B, Jaber S (2013) A trial of intraoperative lowtidal-volume ventilation in abdominal surgery. N Engl J Med 369:428-437

60. Wrigge H, Zinserling J, Neumann P, Muders T, Magnusson A, Putensen C, Hedenstierna G (2005) Spontaneous breathing with airway pressure release ventilation favors ventilation in dependent lung regions and counters cyclic alveolar collapse in oleic-acid-induced lung injury: a randomized controlled computed tomography trial. Crit Care 9:R780-789

61. Kacmarek RM, Villar J, Parrilla D, Alba F, Solano R, Liu S, Montiel R, RicoFeijoo J, Vidal A, Ferrando C, Murcia I, Corpas R, González-Higueras E, Sun Q, Pinedo CE, Pestaña D, Martínez D, Aldecoa C, Añón JM, Soro M, González-Martín JM, Fernández C, Fernández RL, NAVa In Acute respiraTORy failure (NAVIATOR) Network (2020) Neurally adjusted ventilatory assist in acute respiratory failure: a randomized controlled trial. Intensive Care Med. https://doi.org/10.1007/s00134-020-06181-5

62. Anzueto A, Frutos-Vivar F, Esteban A, Bensalami N, Marks D, Raymondos K Apezteguía C, Arabi Y, Hurtado J, González M, Tomicic V, Abroug F, Elizalde J, Cakar N, Pelosi P, Ferguson ND, Ventila G (2011) Influence of body mass index on outcome of the mechanically ventilated patients. Thorax 66:66-73

63. Kalra SS, Siuba M, Panitchote A, Mireles-Cabodevila E, Chatburn RL, Krishnan S, Duggal A (2020) Higher Class of Obesity Is Associated With Delivery of Higher Tidal Volumes in Subjects With ARDS. Respir Care

64. Grasso S, Terragni P, Birocco A, Urbino R, Del Sorbo L, Filippini C, Mascia L, Pesenti A, Zangrillo A, Gattinoni L, Ranieri VM (2012) ECMO criteria for influenza A (H1N1)-associated ARDS: role of transpulmonary pressure. Intensive Care Med 38:395-403

65. De Jong A, Cossic J, Verzilli D, Monet C, Carr J, Conseil M, Monnin M, Cisse M, Belafia F, Molinari N, Chanques G, Jaber S (2018) Impact of the driving pressure on mortality in obese and non-obese ARDS patients: a retrospective study of 362 cases. Intensive Care Med 44:1106-1114

66. Bein T (2018) Driving pressure in obese ventilated patients: another brick in the (chest) wall. Intensive Care Med 44:1349-1351

67. Chiumello D, Colombo A, Algieri I, Mietto C, Carlesso E, Crimella F, Cressoni M, Quintel M, Gattinoni L (2016) Effect of body mass index in acute respiratory distress syndrome. Br J Anaesth 116:113-121

68. Fumagalli J, Berra L, Zhang C, Pirrone M, Santiago RRS, Gomes S, Magni F, Dos Santos GAB, Bennett D, Torsani V, Fisher D, Morais C, Amato MBP, Kacmarek RM (2017) Transpulmonary pressure describes lung morphology during decremental positive end-expiratory pressure trials in obesity. Crit Care Med 45:1374-1381

69. Florio G, Ferrari M, Bittner EA, De Santis SR, Pirrone M, Fumagalli J, Teggia Droghi M, Mietto C, Pinciroli R, Berg S, Bagchi A, Shelton K, Kuo A, Lai Y, Sonny A, Lai P, Hibbert K, Kwo J, Pino RM, Wiener-Kronish J, Amato MBP, Arora P, Kacmarek RM, Berra L (2020) A lung rescue team improves survival in obesity with acute respiratory distress syndrome. Crit Care 24:4

70. Bime C, Fiero M, Lu Z, Oren E, Berry CE, Parthasarathy S, Garcia JGN (2017) High positive end-expiratory pressure is associated with improved survival in obese patients with acute respiratory distress syndrome. Am J Med 130:207-213

71. Zhang Z, Zheng B, Liu N, Ge H, Hong Y (2019) Mechanical power normalized to predicted body weight as a predictor of mortality in patients with acute respiratory distress syndrome. Intensive Care Med 45:856-864

72. Pensier J, de Jong A, Hajjej Z, Molinari N, Carr J, Belafia F, Chanques G, Futier E, Azoulay E, Jaber S (2019) Effect of lung recruitment maneuver on oxygenation, physiological parameters and mortality in acute respiratory distress syndrome patients: a systematic review and meta-analysis. Intensive Care Med 45:1691-1702

73. Fumagalli J, Santiago RRS, Teggia Droghi M, Zhang C, Fintelmann FJ, Troschel FM, Morais CCA, Amato MBP, Kacmarek RM, Berra L (2019) Lung recruitment in obese patients with acute respiratory distress syndrome. Anesthesiology 130:791-803

74. De Santis Santiago R, Teggia Droghi M, Fumagalli J, Marrazzo F, Florio G, Grassi LG, Gomes S, Morais CCA, Ramos OPS, Bottiroli M, Pinciroli R, Imber DA, Bagchi A, Shelton K, Sonny A, Bittner EA, Amato MBP, Kacmarek RM, Berra L, Lung Rescue Team Investigators (2020) High Pleural Pressure Prevents Alveolar Overdistension and Hemodynamic Collapse in ARDS with Class III Obesity. Am J Respir Crit Care Med. https://doi.org/10.1164/ rccm.201909-16870C
75. Guérin C, Beuret P, Constantin JM, Bellani G, Garcia-Olivares P, Roca O, Meertens JH, Maia PA, Becher T, Peterson J, Larsson A, Gurjar M, Hajjej Z, Kovari F, Assiri AH, Mainas E, Hasan MS, Morocho-Tutillo DR, Baboi L, Chrétien JM, François G, Ayzac L, Chen L, Brochard L, Mercat A (2018) A prospective international observational prevalence study on prone positioning of ARDS patients: the APRONET (ARDS Prone Position Network) study. Intensive Care Med 44:22-37

76. De Jong A, Molinari N, Sebbane M, Prades A, Futier E, Jung B, Chanques G, Jaber S (2013) Feasibility and effectiveness of prone position in morbidly obese patients with ARDS: a case-control clinical study. Chest 143:1554-1561

77. Kon ZN, Dahi S, Evans CF, Byrnes KA, Bittle GJ, Wehman B, Rector RP, McCormick BM, Herr DL, Sanchez PG, Pham SM, Griffith BP (2015) Class III obesity is not a contraindication to venovenous extracorporeal membrane oxygenation support. Ann Thorac Surg 100:1855-1860

78. Al-Soufi S, Buscher H, Nguyen ND, Rycus P, Nair P (2013) Lack of association between body weight and mortality in patients on venovenous extracorporeal membrane oxygenation. Intensive Care Med 39:1995-2002

79. Mahul M, Jung B, Galia F, Molinari N, de Jong A, Coisel Y, Vaschetto R, Matecki S, Chanques G, Brochard L, Jaber S (2016) Spontaneous breathing trial and post-extubation work of breathing in morbidly obese critically ill patients. Crit Care 20:346

80. Fernandez MM, Gonzalez-Castro A, Magret M, Bouza MT, Ibanez M, Garcia C, Balerdi B, Mas A, Arauzo V, Anon JM, Ruiz F, Ferreres J, Tomas R, Alabert M, Tizon Al, Altaba S, Llamas N, Fernandez R (2017) Reconnection to mechanical ventilation for $1 \mathrm{~h}$ after a successful spontaneous breathing trial reduces reintubation in critically ill patients: a multicenter randomized controlled trial. Intensive Care Med 43:1660-1667

81. Chanques G, Conseil M, Roger C, Constantin JM, Prades A, Carr J, Muller L, Jung B, Belafia F, Cisse M, Delay JM, de Jong A, Lefrant JY, Futier E, Mercier G, Molinari N, Jaber S (2017) Immediate interruption of sedation compared with usual sedation care in critically ill postoperative patients (SOS-Ventilation): a randomised, parallel-group clinical trial. Lancet Respir Med 5:795-805

82. El-Solh AA, Aquilina A, Pineda L, Dhanvantri V, Grant B, Bouquin P (2006) Noninvasive ventilation for prevention of post-extubation respiratory failure in obese patients. Eur Respir J 28:588-595

83. Neligan PJ, Malhotra G, Fraser M, Williams N, Greenblatt EP, Cereda M, Ochroch EA (2009) Continuous positive airway pressure via the Boussignac system immediately after extubation improves lung function in morbidly obese patients with obstructive sleep apnea undergoing laparoscopic bariatric surgery. Anesthesiology 110:878-884

84. De Jong A, Rollé A, Souche FR, Yengui O, Verzilli D, Chanques G, Nocca D, Futier E, Jaber S (2020) How can I manage anaesthesia in obese patients? Anaesth Crit Care Pain Med 39(2):229-238. https://doi.org/10.1016/j. accpm.2019.12.009

85. Corley A, Bull T, Spooner AJ, Barnett AG, Fraser JF (2015) Direct extubation onto high-flow nasal cannulae post-cardiac surgery versus standard treatment in patients with a $\mathrm{BMI}>$ /=30: a randomised controlled trial. Intensive Care Med 41:887-894

86. Hernandez G, Vaquero C, Colinas L, Cuena R, Gonzalez P, Canabal A, Sanchez S, Rodriguez ML, Villasclaras A, Fernandez R (2016) Effect of postextubation high-flow nasal cannula vs noninvasive ventilation on reintubation and postextubation respiratory failure in high-risk patients: a randomized clinical trial. JAMA 316:1565-1574

87. Fernandez R, Subira C, Frutos-Vivar F, Rialp G, Laborda C, Masclans JR, Lesmes A, Panadero L, Hernandez G (2017) High-flow nasal cannula to prevent postextubation respiratory failure in high-risk non-hypercapnic patients: a randomized multicenter trial. Ann Intensive Care 7:47

88. Lewandowski K, Lewandowski M (2011) Intensive care in the obese. Best Pract Res Clin Anaesthesiol 25:95-108

89. Hutagalung R, Marques J, Kobylka K, Zeidan M, Kabisch B, Brunkhorst F, Reinhart K, Sakr Y (2011) The obesity paradox in surgical intensive care unit patients. Intensive Care Med 37:1793-1799

90. Pickkers P, de Keizer N, Dusseljee J, Weerheijm D, van der Hoeven JG, Peek N (2013) Body mass index is associated with hospital mortality in critically ill patients: an observational cohort study. Crit Care Med 41:1878-1883

91. Decruyenaere A, Steen J, Colpaert K, Benoit DD, Decruyenaere J, Vansteelandt S (2020) The obesity paradox in critically ill patients: a causal learning approach to a casual finding. Crit Care 24:485 